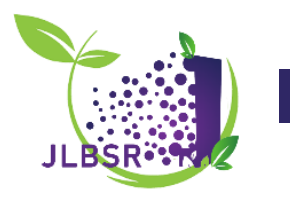

\title{
Determination of IgG and IgM against COVID- 19 for Recovered Patients at Different Intervals and by Different Techniques
}

\author{
Enas Wa'ad Ubaid Al- Hadidi', Mahmood Abdaljabbar Al- Tobje \\ Department of Biology, College of Sciences, Mosul University, Mosul-Iraq \\ (Enass.scp23@student.uomosul.edu.iq,mahtsbio@uomosul.edu.iq) \\ *Correspondence: Enass.scp23@student.uomosul.edu.iq
}

\begin{abstract}
The numbers of infected cases and deaths associated with the novel coronavirus disea-19 (COVID-19), are still increasing daily. Although antibodies have been detected in serum of COVID-19 patients, their dynamics and association with outcomes have not been fully characterized. This study aimed to determine the concentrations of IgG and IgM antibodies for different intervals after recovery from COVID-19, namely 4, 6 and 8 months. Also, to identify the accordance between two types of immunity techniques used to identify the existence of antibodies. The presence of antibodies IgM and IgG to SARS-COV-2 was evaluated in serum samples from recovered patients from COVID-19 over 8 months after infection using ELISA technique and rapid test cassette. The study was conducted in Nineveh Governorate in Iraq on 92 recovering from COVID-19 disease at least two months ago. The results showed the existence of IgG antibodies with a percentage of $94.03 \%$, and IgM antibodies with a percentage of $55.22 \%$ in recruited individuals using ELISA technique. The percentages of these antibodies were $(\mathbf{8 6 . 5 6 \%})$ for IgG and $(\mathbf{1 6 . 4 2 \% )}$ ) for IgM when using a rapid test cassette for diagnosis; the matching was $67 \%$ between the two methods. Samples of the control group also showed the presence of IgG and IgM with percentages of $68 \%$ and $88 \%$ respectively. The average concentrations \pm SD of IgG antibodies were $33.05 \pm 10.76,43.21 \pm 4.5$ and $37.53 \pm 8.82$ at $P \geq 0.01$ after 4,6 and 8 months after infection respectively; the peak was at the 6 th month after infection. The averages of $\mathrm{IgM} \pm \mathrm{SD}$ were $14.45 \pm 3.3,18.52 \pm 3.86$ and $19.18 \pm 3.61$ at $\mathrm{P}<0.05$ after 4,6 and 8 months of being infected respectively; the peak was at the 8th month after infection. It was concluded that the presence of antibodies against SARS-CoV-2 continued for six months after infection and its level began to decrease gradually after eight months of infection whereas the concentration of IgM depends on the patient's exposure again to the virus during recovery period.
\end{abstract}

Keywords: ELISA, IgG, IgM, Rapid test cassette

Received: December $8^{\text {th }} 2021 /$ Accepted: $20^{\text {th }}$ January, $2022 /$ Online: $26^{\text {th }}$ January, 2022

\section{INTRODUCTION}

In the year 2019, virus SARS- COV- 2 and acute respiratory infection was diagnosed for the first time in China, and it was called COVID-19 (Figueiredo-Campos et al., 2020). It is of great importance to deal with COVID-19 epidemic in case of future spread or in regard to developing new strategies of sustainable vaccination to determine the activity and the pattern of immunity. Therefore, it is necessary to acquire further accepting of the immunity duration and its relatedness to disease harshness and clinical management (Sasisekharan et al., 2021).

After 7- 14 days from infection by SARS-COV-2, seroconversion takes place (Krajewski et al., 2020; Long et al., 2020a; To et al., 2020) with the presence of peak in the level of antibodies which was seen in 30- 35 days after the manifestation of symptoms (Crawford et al., 2020; Wang et $a l ., 2020)$. Rapid decline was noticed in the concentration of (anti- SARS- COV- 2 IgG antibodies) for a period of about 3 months after being infected (Beaudoin-Bussiere et al., 2020; Röltgen et al., 2020), while there was stability in the titer of antibodies for several months, the thing that indicates the presence of long-term immunity (Gudbjartsson et al., 2020; Wang et al., 2020; Liu et al., 2021). COVID- 19 cases are confirmed through the detection of virus RNA sequences using (NAAT) test, such as (RT-PCR) in phlegm and throat swabs of lower respiratory system (WHO, 2020; Vengesai et al., 2021), and the standard reference method rRt- PCR diagnoses the infection of SARS- COV-2 accurately and with great sensitivity in the acute stage of COVID- 19 (Lee et al., 2020).

Serological checks can be completed more quickly and with higher productivity and less cost and work burden (Lee et al, 2020; Wolff et al., 2020) and when the virus is present in patients less than the detection border of RT- PCR criteria, then diagnosis becomes of high value and can be used in 
complementation to NAATs (Wolff et al., 2020; To et al., 2020), however, the first diagnosis of COVID- 19 using serological check only might not be probable since seroconversion takes pace usually within 3-14 days after the manifestation of the disease. The specificity and sensitivity of the tests are certainly affected by the period of infection (Wang et al., 2020). In general, serological checks can be appropriate in the following cases: 1- Diagnosis through 7 days of symptoms appearance, 2- Diagnosis with RT- PCR negative tests and having epidemical and clinical evidence that indicate being infected with COVID- 19, 3- Tracing patient contacts, 4- Determining probable immunity and protection against reinfection, 5-Serological epidemiological studies to recognize the spread of COVID- 19 in the society (Lassaunière et al., 2020; Lou et al., 2020; Rastawicki et al., 2020).

Serological tests for diagnosis include (ELISAs) assays, (CLIAs) assay and (LFIAs) assay, in addition to that neutralization assays (NT) (Ravi et al., 2020). The current study aimed to iidentify the most sensitive and accurate technique to diagnose the infection and the degree of matching between techniques. Also, to determine the period of retention for $\mathrm{IgG}$ and $\operatorname{IgM}$ antibodies after infection and recovery from the disease.

\section{MATERIALS AND METHODS}

\section{A. Materials}

The research was conducted in Nineveh Governorate in Iraq on 92 individuals, 67 were infected with COVID-19 disease recovered at least two months ago and 25 control samples. 92 blood samples were collected of which 67 from recovered patients from COVID- 19 for a period of recovery not less than two months, and 25 blood samples from individuals that showed no symptoms of ages (17-75) years and during the period from October/2020 to March/ 2021. Patient information were recorded in an information form which included: sample number, age, gender, date of infection, date of recovery, symptoms that the patient suffered during infection, comorbidities, treatments used and place of residency. Samples collection included three different time intervals (4 months, 6 months and 8 months) after infection with COVID- 19.

\section{B. Preparation of blood serum}

$5 \mathrm{ml}$ of venous blood was drawn via sterile medical syringe, put in gel tube and left for half an hour till blood coagulation took place, and serum separated using centrifuge at (3000) rpm for (15) minutes, and then distributed on a number of eppendorf tubes. The samples were then preserved at $(-20)$ $\mathrm{C}_{\mathrm{o}}$ until the required tests were conducted.

\section{Serological methods}

Two different Serological methods were used for detection of antibodies of COVID-19.

\section{ELISA}

COVID- 19 IgG- IgM detection kit was used from (Vircell Spain S.L.U., Granada, Spain), Vircell COVID- 19 ELISA IgG. These tests use SARS- COV- 2 antigen of (S) protein and $(\mathrm{N})$ Protein, and when the diluted samples were added and during the incubation period, COVID- 19 antibodies link with their antigens, and after washing, the antibodies marked with enzyme were added with which the complex in the pits associate to cause color change when adding the base material of the enzyme. The intensity of color is directly proportional with the concentration of the antibodies in the sample, the reaction is stopped using an acid solution, and then light intensity is measured at (450) $\mathrm{nm}$ and results are calculated allowing:

$\mathrm{Ab}$ - index $=$ (sample O.D. /cut off serum mean O.D. $) \times 10$

Results: Positive values $\geq 6.0$, negative values $<4.0$, and questionable values :4.0 to 6.0, (Wölfel et al., 2020)

\section{Rapid test cassette}

Using cassette test to detect the existence of COVID-19 virus antibodies; IgG and IgM supplied by (Biozek Medical,). Immunochromatographic test as used for the fast lateral flow qualitative discovery of $\operatorname{IgG}, \operatorname{IgM}-\mathrm{Ab}$ of SARS- COV-2 in blood according to the instructions of the manufacturer; the result was read within 10- 15 minutes (Cui et al. 2019).

\section{Statistical analysis}

Statistical analysis of the data was conducted via Kappa program to find the percentage of matching between different methods (McHugh, 2012) and the Statistical Package for Social Science (SPSS) version 25 (SPSS Inc., Chicago, IL) program was used in the statistical analysis for the purpose of finding the significant relationship and extracting a p-value (Kirkwood and Sterne, 1988).

\section{RESULTS}

Two serological methods were followed to identify the presence of Diseases IgG, IgM -Ab in the serum, namely: ELISA and Rapid test Cassette and table (1) shows that the total number of the diagnosed samples was (67) of which (63) gave positive result for IgG antibodies according to ELISA with a percentage of $(94.03 \%)$. Tests were also conducted on (25) samples of healthy people who showed no symptoms of infection, as control samples, of which (17)

Table 1. Methods used in identifying positive samples of $\operatorname{IgG}$ and $\operatorname{IgM}$ in individuals and their percentages after 4 months of infection

\begin{tabular}{|c|c|c|c|c|c|c|c|c|c|c|}
\hline & \multicolumn{9}{|c|}{ EISA } & \multicolumn{4}{c|}{ Rapid test cassette } \\
\cline { 2 - 11 } Antibodies & total & $\begin{array}{c}\text { Positive } \\
\text { samples } \\
\%\end{array}$ & $\begin{array}{c}\text { Percentage } \\
\%\end{array}$ & $\begin{array}{c}\text { Total } \\
\text { control } \\
\text { sample }\end{array}$ & $\begin{array}{c}\text { Positive } \\
\text { control } \\
\text { samples }\end{array}$ & $\begin{array}{c}\text { percentage } \\
\%\end{array}$ & $\begin{array}{c}\text { Positive } \\
\text { samples }\end{array}$ & $\begin{array}{c}\text { percentage } \\
\%\end{array}$ & $\begin{array}{c}\text { Positive } \\
\text { control } \\
\text { samples }\end{array}$ & percentage \\
IgG & 67 & 63 & 94.03 & 25 & 17 & 68 & 58 & 86.56 & 13 & 52 \\
IgM & 67 & 37 & 55.22 & 25 & 22 & 88 & 11 & 16.42 & 10 & 40 \\
6
\end{tabular}


had IgG antibodies with a percentage of $(68.56 \%)$. IgM antibodies were found in (37) persons with a percentage of $(55.22 \%)$ and in (22) persons of the control sample with a percentage of $(88 \%)$. In the other hand, when Rapid test cassette was used, there were (58) persons out of the total number that showed positive results for $\mathrm{IgG}$ with a percentage of $(86.56 \%)$ and (13) of the control samples showed positive IgG with a percentage of $(52 \%)$, whereas $\operatorname{IgM}$ appeared in (11) persons with a percentage of $(16.42 \%)$ and in the control samples in (10) persons with a percentage of $(40 \%)$.

Through the performance of statistical analysis of results, the match ratio between the two methods was found to be $(67 \%)$ and this result indicates medium matching between the two techniques.

Sensitivity and specificity are two quantitative standards to evaluate methods of diagnosis (Mandrekar, 2010), where sensitivity pointing to the ability of the test to determine the least possible amount of antibodies in the sample, and the higher the sensitivity of the test was, the less false- negative results obtained.

As for specificity, it is the ability of the test to qualitative determination of antibodies under investigation, and the more specific the test was, the more accurate the results we get ( $\mathrm{Li}$ et al., 2020: Goudouris, 2021). Sufficient specificity and sensitivity eventually lead to optimal diagnosis.

Among several studies that addressed the determination of Rapid test cassette sensitivity, only few of them proved it to be of good sensitivity which varied between 90\% - 100\% (Zhao et al., 2020; Zhong et al., 2020; Yang et al., 2020). Many other studies have proved that it was of low sensitivity (Yang et al., 2020; Pan et al., 2020; To et al., 220; Xu et al., 2020) and this is in line with the results we came to. The sensitivity values of test kits vary according to the type of test and the manufacture. A comparative study was conducted among the different methods for diagnosing infection with COVID- 19 and found that ELISA was the most sensitive among other methods used to diagnose infection with COVID-19 (Zhong et al., 2020).

In general, ELISA has superior diagnostic accuracy in determining the concentration of $\mathrm{IgG}$ and $\operatorname{IgM}$ with sensitivity and specificity that reached $(85 \%)$ and $(99 \%)$ respectively (Vengesai et al., 2021) and this is in congruency with the results we obtained. The sensitivity results in this statistic study is compatible with the statistical analysis which showed that Rapid test cassette has less sensitivity than CLIA and ELISA in each class of antibodies (Deeks et al., 2020; Bastos et al., 2020; Wang et al., 220). This contradicted the statistical analysis by Deeks et al. who found that regarding IgG and IgG- IgM, the Rapid test cassette had higher sensitivity than ELISA (Deeks et al., 2020).

According to another statistical analysis, serological tests to determine the level of IgM had the lowest sensitivities compared to serological test to determine the level of IgG in each method (Deeks et al., 2020; Bastos et al., Wang et al., 2020) and this is in line with our study. Low concentrations of IgM may be due to its late formation after the infection or due to the late performance of test till their disappearance (Kontou et al., 2020).

Table 2. The mean concentration of $\operatorname{IgG}$ and $\operatorname{IgM} \pm \mathrm{SD}$ antibodies in the three intervals.

\begin{tabular}{|c|c|c|c|c|c|c|c|c|}
\hline $\operatorname{Ig}$ & Total Number & $\begin{array}{l}\text { Number of } \\
\text { positive } \\
\text { samples after } \\
4 \text { months }\end{array}$ & $\begin{array}{c}\text { Mean } \pm \text { SD } \\
\mathrm{IU} / \mathrm{ml}\end{array}$ & $\begin{array}{l}\text { No. of }+^{\mathrm{ve}} \\
\text { samples after } \\
6 \text { months }\end{array}$ & $\begin{array}{c}\text { Mean } \pm \text { SD } \\
\mathrm{IU} / \mathrm{ml}\end{array}$ & $\begin{array}{l}\text { No. of }+^{\text {ve }} \\
\text { samples after } \\
8 \text { months }\end{array}$ & $\begin{array}{c}\text { Mean } \pm \text { SD } \\
\mathrm{IU} / \mathrm{ml}\end{array}$ & P-value \\
\hline $\mathrm{IgG}$ & 48 & 48 & $33.05 \pm 10.76$ & 48 & $43.21 \pm 4.5$ & 48 & $37.53 \pm 8.82$ & $P \geq 0.01$ \\
\hline IgM & 48 & 28 & $14.45 \pm 3.3$ & 30 & $18.52 \pm 3.86$ & 36 & $19.18 \pm 3.61$ & $\mathrm{P}<0.05$ \\
\hline
\end{tabular}

Table (2) demonstrates the mean concentrations \pm standard deviation (SD) of $\operatorname{IgG}$ and $\operatorname{IgM}$ antibodies during the three intervals; the average concentration $\pm \mathrm{SD}$ of $\mathrm{IgG}$ was $(33.05 \pm$ 10.76) $\mathrm{IU} / \mathrm{ml}$ in the first interval, increased to $(43.21 \pm 4.5)$ $\mathrm{IU} / \mathrm{ml}$ in the second interval, and started to decline as it was $(37.53 \pm 8.82)$ IU in the third at $(\mathrm{P} \geq 0.01)$. The average $\pm \mathrm{SD}$ of $\mathrm{IgM}$ was $(14.45 \pm 3.3) \mathrm{IU} / \mathrm{ml}$ in the first interval, increased to $(18.52 \pm 3.86) \mathrm{IU} / \mathrm{ml}$ and maintained a close average in the third interval with $(19.15 \pm 3.61) \mathrm{IU} / \mathrm{ml}$ at $(\mathrm{P}<0.05)$. We may conclude that we have a reduced IgG average at 8 months after infection whereas the concentration of $\operatorname{IgM}$ depends on the patient's exposure again to the virus during recovery period.

Evidence indicate that adults infected confirmed with RTPCR develop IgM antibodies with a percentage up to $(80 \%)$ after 20 days of symptoms manifestation (Dave et al., 2020; Liu et al., 2020; Shu et al., 2020) and the results of these studies indicate also that $\operatorname{IgM}$ antibodies are first noticed in an average of 7 days and begin to decline in 27 days and this contradicts our study.
Many other studies also showed that the heights of IgG against SARS- COV-2 did not decline after 4 months of infection and it continued to 6 months after the appearance of symptoms (Zhao et al., 2020; Isho et al., 2020; Dan et al., 2020; Lee et al., 2020; Figueiredo et al., 2020; Liu et al., 2020; Wang et al., 2020; Cervia et al., 2021; Marklund et al., 2021; Wajnberg et al., 2020).

Another study which lasted for about 8 months found that $(95 \%)$ of individuals who developed IgG had a slight decline in its concentration after 3 months, and $\operatorname{IgG}$ bodies still present with a percentage of $90 \%$ after 8 months. IgA and IgM antibodies were less common and there levels declined faster in 8 months at which IgM antibodies were not seen. Age and severity of infection are independently associated with the high levels of IgG antibodies (Glück et al., 2021).

Some reports indicate that IR to SARS- COV- 2 could decrease rapidly (Ibarrondo et al., 2020; Brochot et al., 2020) and a big percentage of patients go back to seronegative (Self et al., 2020), the study results, with other studies, proved that anti-SARS- COV- 2 IgG may keep a stable level respectively 
or show a slow reduction for 6 months at least (Isho et al., 2020; Dan et al., 2020; Wajnberg et al., 2020; Iyer et al., 2020; Choe et al., 2021) and this coincides with the results we obtained; IgG antibodies were seen with the highest level at 6 months and started to decine at 8 months. This also coincides with another study that followed COVID-19 cases for 6 months and found that antibodies persist in all cases after 6-7 months from COVID- 19 infection in addition to $\mathrm{T}$ - cell memory (Tan et al., 2020).

Many recent studies have showed that most patients have responses $(\mathrm{Ab})$ to SARS- COV- 2 that can be seen after 6-8 months from infection (Crawford et al., 2020; Iyer et al., 2020, Wajnberg et al., 2020; Grandjean et al., 2020; Seow et al., 2020; Gudbjartsson et al., 2020).

\section{CONCLUSION}

The highest $\mathrm{IgG}$ antibodies level was seen after 6 months of infection whereas the highest level of IgM antibodies was seen in the eighth month after infection. ELISA was the more sensitive and accurate technique in diagnosis of antibodies than Rapid test cassette and the percentage of accordance between them was $67 \%$.

\section{REFERENCE}

Bastos, L., Tavaziva, M., Abidi, G., Campbell, S.K., Haraoui, J.R., Johnston, L.P., Lan, J.C., et al. (2020). Diagnostic Accuracy Of Serological Tests For COVID-19: Systematic Review And Meta-Analysis. $B M J, 1,370, \mathrm{M} 2516$.

Beaudoin-Bussières, G., Laumaea, A., Anand, S.P., Prévost, J., Gasser, R., Goyette, G., Medjahed, H., et al. (2020). Decline of Humoral Responses against SARS-CoV-2 Spike in Convalescent Individuals. mBio, 11(5), e02590-20.

Brochot, E., Demey, B., Touzé, A., Belouzard, S., Dubuisson, J., Schmit, J.L., Duverlie, G., et al. (2020). Anti-spike, Anti-nucleocapsid and Neutralizing Antibodies in SARS-CoV-2 Inpatients and Asymptomatic Individuals. Front Microbiol, 11, 584251.

Cervia, C., Nilsson, J., Zurbuchen, Y., Valaperti, A., Schreiner, J., Wolfensberger, A., Raeber, M.E., et al. (2021). Systemic and mucosal antibody responses specific to SARS-CoV-2 during mild versus severe COVID-19. J Allergy Clin Immunol, 147(2),545557.e9.

Choe, P.G., Kim, K.H., Kang, C.K., Suh, H.J., Kang, E., Lee, S.Y., et al. (2021). Antibody Responses 8 Months after Asymptomatic or Mild SARS-CoV-2 Infection. Emerg Infect Dis, 27(3),928-931.

Crawford, K.H.D., Dingens, A.S., Eguia, R., Wolf, C.R., Wilcox, N., Logue, J.K., Shuey, K., et al. (2021). Dynamics of Neutralizing Antibody Titers in the Months After Severe Acute Respiratory Syndrome Coronavirus 2 Infection. J Infect Dis, 223 (2),197-205.

Cui, J., Li, F., Shi, Z.L. (2019). Origin and evolution of pathogenic coronaviruses. Nat Rev Microbial, 17,181-192.

Dan, J.M., Mateus, J., Kato, Y., Hastie, K.M., Yu, E.D., Faliti, C.E., Grifoni, A., et al. (2021). Immunological memory to SARS-CoV-2 assessed for up to 8 months after infection. Science, 371(6529), eabf 4063 .

Dave, M., Poswal, L., Bedi, V., Regar, L., Vijayvargiya, R., Sharma, M. Deval, N. (2020). Study of Antibody-based Rapid Card Test in COVID-19 Patients Admitted in a Tertiary Care COVID Hospital in Southern Rajasthan. Journal Indian Academy of Clinical Medicine. 21, 7-11.

Deeks, J.J., Dinnes, J., Takwoingi, Y., Davenport, C., Spijker, R., TaylorPhillips, S., Adriano, A. (2020). Cochrane COVID-19 Diagnostic Test Accuracy Group. Antibody Tests for Identification of Current and Past Infection with SARS-CoV-2. Cochrane Database Syst Rev. 6 (6), CD013652.
Figueiredo-Campos, P., Blankenhaus, B., Mota, C., Gomes, A., Serrano, M., Ariotti, S., Costa, et al. (2020). Seroprevalence of Anti-SARSCoV-2 Antibodies in COVID-19 Patients and Healthy Volunteers up to 6 Months Post Disease Onset. Eur J Immunol. 50(12),20252040.

Glück, V., Grobecker, S., Tydykov, L., Salzberger, B., Glück, T., Weidlich, T., Bertok, M., et al. (2021). SARS-CoV-2-Directed Antibodies Persist for More Than Six Months in a Cohort with Mild to Moderate COVID-19. Infection. 49(4),739-746.

Goudouris, E.S. (2021). Laboratory Diagnosis of COVID-19. J. Pediatr. Rio $J, 97,7-12$.

Grandjean, L., Saso, A., Torres, A., Lam, T., Hatcher, J., Thistlethwayte, R., Harris, M. (2020). Humoral Response Dynamics Following Infection with SARSCoV-2. medRxiv, 2020.07.16.20155663.

Gudbjartsson, D.F., Norddahl, G.L,, Melsted P, Gunnarsdottir K, Holm H, Eythorsson E, Arnthorsson AO, et al. (2020). Humoral Immune Response to SARS-CoV-2 in Iceland. $N$ Engl $J \mathrm{Med}$, 383(18), 1724-1734.

Ibarrondo, F.J., Fulcher, J.A., Goodman-Meza, D., Elliott, J., Hofmann, C., Hausner, M.A., Ferbas, K.G., et al. Rapid Decay of Anti-SARSCoV-2 Antibodies in Persons with Mild COVID-19. N Engl J Med, 383(11), 1085-1087.

Isho, B., Abe, K.T., Zuo, M., Jamal, A.J., Rathod, B., Wang, J.H., Li, Z., et al. (2020). Persistence of serum and saliva antibody responses to SARS-CoV-2 spike antigens in COVID-19 patients. Sci Immunol, 8,5(52), eabe5511.

Iyer, A.S., Jones, F.K., Nodoushani, A., Kelly, M., Becker, M., Slater, D, Mills, R., et al. (2020). Persistence and decay of human antibody responses to the receptor binding domain of SARS-CoV-2 spike protein in COVID-19 patients. Sci Immunol, 5, eabe0367.

Kirkwood, B.R., Sterne, J.A.C. (1988). Medical Statstic. $6^{\text {th }}$ ed. Blackwell publication company.

Kontou, P.I., Braliou, G.G., Dimou, N.L., Nikolopoulos, G., Bagos, P.G. (2020). Antibody Tests in Detecting SARS-CoV-2 Infection: A Meta-Analysis. Diagnostics (Basel). 19,10(5),319.

Krajewski, R., Gołębiowska, J., Makuch, S., Mazur, G., Agrawal, S. (2020). Update on serologic testing in COVID-19. Clin Chim Acta, $510,746-750$

Lassaunière, R., Frische, A., Harboe, Z.B., $\quad$ Nielsen, $\quad$ A.C.Y., Fomsgaard, A., Krogfelt, K.A., Jørgensen, C.S. (2020). Evaluation of nine commercial SARS-CoV-2 immunoassays. Medrxiv, 1-15.

Lee, C.Y., Lin, R.T.P., Renia, L., Ng, L.F.P. (2020). Serological Approaches for COVID-19: Epidemiologic Perspective on Surveillance and Control. Front Immunol, 24,11,879.

Lee, W.T., Girardin, R.C., Dupuis, A.P., Kulas, K.E., Payne, A.F., Wong, S.J., Arinsburg, S., et al. (2020). Neutralizing Antibody Responses in COVID-19 Convalescent Sera. J Infect Dis, 4,223(1),47-55.

Li, C., Zhao, C., Bao, J., Tang, B., Wang, Y., Gu, B. (2020). Laboratory diagnosis of coronavirus disease-2019 (COVID-19). Clin Chim Acta, 510,35-46.

Li, Z., Yi, Y., Luo, X., Xiong, N., Liu, Y., Li, S., Sun, R., et al. (2020). Development and clinical application of a rapid $\operatorname{IgM}-\operatorname{IgG}$ combined antibody test for SARS-CoV-2 infection diagnosis. $J$ Med Virol, 92(9),1518-1524.

Liu, C., Yu, X., Gao, C., Zhang, L., Zhai, H., Hu, Y., Liu, E., et al. (2021). Characterization of antibody responses to SARS-CoV-2 in convalescent COVID-19 patients. J Med Virol, 93(4),2227-2233.

Liu, X., Wang, J., Xu, X., Liao, G., Chen, Y., Hu, C.H. (2020). Patterns of IgG and IgM antibody response in COVID-19 patients. Emerg Microbes Infect, 9(1),1269-1274.

Long, Q.X., Liu, B.Z., Deng, H.J., Wu, G.C., Deng, K., Chen, Y.K., Liao, P., et al. (2020). Antibody responses to SARS-CoV-2 in patients with COVID-19. Nat Med, 26(6),845-848.

Lou, B., Li, T.D., Zheng, S.F., Su, Y.Y., Li, Z.Y., Liu, W., Yu, F., et al. (2020). Serology characteristics of SARS-CoV-2 infection after exposure and post-symptom onset. Eur Respir $J$, 27,56(2),2000763.

Mandrekar, J.N. (2010). Simple Statistical Measures for Diagnostic Accuracy Assessment. J Thorac Oncol, 5, 763-764.

Marklund, E., Leach, S., Axelsson, H., Nyström, K., Norder, H., Bemark, M., Angeletti, D., et al. (2020). Serum-IgG responses to SARS-CoV-2 
after mild and severe COVID-19 infection and analysis of IgG non-responders. PLoS One, 21,15(10),e0241104. Erratum in: PLoS One, 2021,16(10), $\mathrm{e} 0258401$.

McHugh, M.L. Interrater Reliability: The Kappa Statistic. (2012). Biochem Medica, 22(3),276-82.

Pan, Y., Li, X., Yang, G., Fan, J., Tang, Y., Zhao, J., Long, X., et al. (2020). Serological Immunochromatographic Approach in Diagnosis with SARS-CoV-2 Infected COVID-19 Patients. J Infect, 81(1),e28e32.

Rastawicki, W., Rokosz-Chudziak, N. (2020). Characteristics and Assessment of the Usefulness of Serological Tests in the Diagnostic of Infections Caused by Coronavirus SARS-CoV-2 on the Basis of Available Manufacturer's Data and Literature Review. Przegl Epidemiol, 74(1),49-68.

Ravi, N., Cortade, D.L., Ng, E., Wang, S.X. (2020). Diagnostics for SARSCoV-2 Detection: A Comprehensive Review of the FDA-EUA COVID-19 Testing Landscape. Biosens Bioelectron, 165,112454.

Röltgen, K., Powell, A.E., Wirz, O.F., Stevens, B.A., Hogan, C.A., Najeeb, J., Hunter, M., et al. (2020). Defining the Features and Duration of Antibody Responses to SARS-CoV-2 Infection Associated with Disease Severity and Outcome. Sci Immunol, 5(54),eabe0240.

Sasisekharan, V., Pentakota, N., Jayaraman, A., Tharakaraman, K., Wogan, G.N., Narayanasami, U. (2021). Orthogonal Immunoassays for IgG Antibodies to SARS-CoV-2 Antigens Reveal that Immune Response Lasts Beyond 4 Mo Post Illness Onset. Proc Natl Acad Sci U S A. 118(5),e2021615118.

Self, W.H., Tenforde, M.W., Stubblefield, W.B., Feldstein, L.R., Steingrub, J.S., Shapiro, N.I., Ginde A.A., et al. (2020). CDC COVID-19 Response Team; IVY Network. Decline in SARS-CoV-2 Antibodies After Mild Infection Among Frontline Health Care Personnel in a Multistate Hospital Network - 12 States. MMWR Morb Mortal Wkly Rep, 69(47), 1762-1766

Seow, J., Graham, C., Merrick, B., Acors, S., Pickering, S., Steel, K.J.A., Hemmings, O. et al. (2020). Longitudinal Observation and Decline of Neutralizing Antibody Responses in the Three Months Following SARS-Cov-2 Infection In Humans. Nature Microbiology, 5,1598-607.

Shu, H., Wang, S., Ruan, S., Wang, Y., Zhang, J., Yuan, Y., Liu, H., et al. (2020). Dynamic Changes of Antibodies to SARS-CoV-2 in COVID-19 Patients at Early Stage of Outbreak. Virol Sin, 35(6),744-751.

Tan, Y., Liu, F., Xu, X., Ling, Y., Huang, W., Zhu, Z., Guo, M., et al. (2020). Durability of Neutralizing Antibodies and T-cell Response Post SARS-CoV-2 Infection. Front Med, 14(6),746-751.

To, K.K., Tsang, O.T., Leung, W.S., Tam, A.R., Wu, T.C., Lung, D.C., Yip, C.C., et al. (2020). Temporal Profiles Of Viral Load In Posterior Oropharyngeal Saliva Samples and Serum Antibody Responses
During Infection by SARS-Cov-2: An Observational Cohort Study. Lancet Infect Dis, (5),565-574.

Vengesai, A., Midzi, H., Kasambala, M., Mutandadzi, H., Mduluza-Jokonya, T.L., Rusakaniko, S., Mutapi, F., et al. (2021). A Systematic and Meta-Analysis Review on The Diagnostic Accuracy of Antibodies in The Serological Diagnosis Of COVID-19. Syst Rev, 10(1),155.

Wajnberg, A., Amanat, F., Firpo A., Altman, D.R. Bailey, M.J., Mansour, M., McMahon, M., et al. (2020). SARS-CoV-2 Infection Induces Robust, Neutralizing Antibody Responses That are Stable for at Least Three Months. medRxiv, 2020.07.14.20151126.

Wang, H., Ai, J., Loeffelholz, M.J., Tang, Y.W., Zhang, W. (2020). MetaAnalysis of Diagnostic Performance of Serology Tests for COVID19: Impact of Assay Design and Post-Symptom-Onset Intervals. Emerg Microbes Infect, 9(1),2200-2211.

Wang, K., Long, Q.X., Deng, H.J., Hu, J., Gao, Q.Z., Zhang, G.J., He, C.L., et al. (2021). Longitudinal Dynamics of the Neutralizing Antibody Response to Severe Acute Respiratory Syndrome Coronavirus 2 (SARS-CoV-2) Infection. Clin Infect Dis. 73(3),e531-e539.

Wang, P., Liu, L., Nair, M.S., Yin, M.T., Luo, Y., Wang, Q., Yuan, T., et al. (2020). SARS-CoV-2 Neutralizing Antibody Responses are More Robust in Patients with Severe Disease. Emerg Microbes Infect, 9(1),2091-2093.

WHO. Laboratory testing for coronavirus disease 2019 (COVID-19) in suspected human cases: interim guidance. (2020). World Health Organization; 2020

Wölfel, R., Corman, V.M., Guggemos, W., Seilmaier, M., Zange, S., Müller, M.A., Niemeyer, D., et al. (2020). Virological assessment of hospitalized patients with COVID-2019. Nature. 581(7809),465469. Erratum in: Nature, 588(7839), E35.

Wolff, F., Dahma, H., Duterme, C., Van den Wijngaert, S., Vandenberg, O., Cotton, F., Montesinos, I. (2020). Monitoring Antibody Response Following SARS-CoV-2 Infection: Diagnostic Efficiency of 4 Automated Immunoassays. Diagn Microbiol Infect Dis, 98(3), 115140

Xu, Y., Xiao, M., Liu, X., Xu, S., Du, T., Xu, J., Yang, Q., et al. (2020). Significance of Serology Testing to Assist Timely Diagnosis of SARS-CoV-2 Infections: Implication from a Family Cluster. Emerg Microbes Infect, 9(1),924-927.

Yang, T., Gentile, M., Shen, C.F., Cheng, C.M. (2020). Combining Point-ofCare Diagnostics and Internet of Medical Things (IoMT) to Combat the COVID-19 Pandemic. Diagnostics (Basel), 10(4),224.

Zhao, J., Yuan, Q., Wang, H., Liu, W., Liao, X., Su, Y., Wang, X., et al. (2020). Antibody Responses to SARS-CoV-2 in Patients with Novel Coronavirus Disease 2019. Clin Infect Dis, 71(16),20272034.

Zhong, L., Chuan, J., Gong, B., Shuai, P., Zhou, Y., Zhang, Y., Jiang, Z. (2020). Detection of serum IgM and IgG for COVID-19 diagnosis. Sci. China Life Sci, 63,777. 